\title{
Waste Management Based on Banjar and Customary Village in Denpasar City-Bali
}

\author{
I Made Suwitra ${ }^{1}$, I Nyoman Sukandia ${ }^{1}$, I Wayan Subawa ${ }^{1}$, I Wayan Arthanaya ${ }^{1}$, \\ Diah Gayatri Sudibya ${ }^{1}$, Ni Putu Sawitri Nandari ${ }^{2}$ \\ ${ }^{1}$ Faculty of Law, Universitas Warmadewa, Denpasar, Bali, Indonesia \\ ${ }^{2}$ Faculty of Law, Universitas Pendidikan Nasional, Denpasar, Bali, Indonesia
}

\section{Email address:}

madesuwitra27@gmail.com (I M. Suwitra),nyomansukandia@gmail.com (I N. Sukandia), sbw54@gmail.com (I W. Subawa), diahgayatrisudibya@gmail.com (D. G. Sudibya),arthanaya.wayan@gmail.com (I W. Arthanaya),

sawitrinandari@gmail.com (N.P. S. Nandari)

\section{To cite this article:}

I Made Suwitra, I Nyoman Sukandia, I Wayan Subawa, I Wayan Arthanaya, Diah Gayatri Sudibya, Ni Putu Sawitri Nandari. Waste Management Based on Banjar and Customary Village in Denpasar City-bali. International Journal of Law and Society.

Vol. 3, No. 1, 2020, pp. 12-19. doi: 10.11648/j.ijls.20200301.13

Received: February 21, 2020; Accepted: March 27, 2020; Published: April 14, 2020

\begin{abstract}
Each of residents of Denpasar City produces 4 liters of waste per day. With a population of 788,589 people in 2011, the waste generated reaches $1.151 .341,40 \mathrm{~m}^{3}$ per year. While the transportation capacity of the trucks of Sanitation and Gardening Service (DKP) reachs $698,949 \mathrm{~m} 3$ of waste or $60.71 \%$ of the total waste, so DKP Denpasar City has not been able to reach the service target of $80 \%$ of the total waste. By Mayor Regulation No. 11 year 2016 there is change paradigm of environment-based waste management in banjar and desa adat / customary village with the aim that the waste has been managed from the source so that waste disposed to landfill (TPA) can be reduced. The methods used are normative legal research and empirical law research with legal, analytic, philosophical and customary or cultural approaches. Denpasar City Government wishes to exude local law product with custom law in waste management including its supervision and law enforcement (Top and Botton Up) model. With this model, the waste management is done in each Banjar / Neighborhoods and Desa Adat / village through the procurement of TPS (laystall)/TPST (temporary laystall). While DKP only serves the transportation from TPS (laystall) to TPA (landfill). Sanctions against violation of waste disposal shall be a maximum fine of 50 million rupiah or maximum 3 (three) months imprisonment.
\end{abstract}

Keywords: Waste, Banjar, Sanction

\section{Background}

Counties and cities in Bali has made various efforts in waste management, but to date has not shown the maximum results because the waste can still be found everywhere, such as on sidewalks, vacant lots, ditches / drains, streets, alleys, ravines especially in markets. This condition occurs, because the regulation is still possible for residents to place their garbage in front of their houses or alleys to be transported by trucks owned by the City Government, namely DKP, so that every afternoon can be found many garbage trucks that are taking garbage residents placed in Front of house or alley or sidewalk. Not infrequently these garbage trucks can cause congestion because they are simultaneously raising the garbage on the left and on the right.

In Denpasar it is assumed, that every resident produces 4 liters of waste per day. With the total population of the city of Denpasar which reached 788,589 in 2011, the waste generated reached $1.151 .341 .40 \mathrm{~m} 3$ while the capacity of DKP truck reached $698,949 \mathrm{~m} 3$ of garbage or $60.71 \%$ of the total waste. This indicates DKP has not achieved service target of $80 \%$ of total waste [1]. ${ }^{1}$

Denpasar City, Badung regency, Gianyar and Tabanan regency (Sarbagita) have cooperated in the management of waste disposal site (TPA) in Suung Sanggaran through cooperation with private parties. The goal is to provide

1 Waste and the carrying capacity of DKP year 2005-2011 data, www.denpasarkota.go.id, accessed January, 16, 2017. 
economic benefits to the community such as electricity, methane gas for cooking. However, since the waste has not been managed from the source with the $3 \mathrm{R}$ principle, the TPA Suung has not provided the benefits as expected. Even cattle that roam around and eat the rest of the waste will be very dangerous if the meat is consumed by humans.

State Presence through Law no. 18 year 2008 on Waste Management [2] and Government Regulation no. 81 year 2012 on the Management of Household Waste and similar waste strengthen the legal basis for dealing with waste management in Indonesia, particularly in the regions [3]. Some of the key and important content mandated by this Government Regulation are as follows:

1) Provide a stronger foundation for local government in the implementation of waste management from various aspects environmentally friendly such as legal formal, management, technical operational, financing, institutional, and human resources;

2) Provide clarity regarding the distribution of tasks and the role of all parties involved in waste management from ministries / agencies at the central level, Provincial Government, District / City Government, business community, area manager to the community;

3) Provide operational base for the implementation of $3 R$ (reduce, reuse, recycle) in waste management to replace the old collect-haul-away paradigm;

4) Provide a strong legal foundation for the involvement of the business world to participate in the management of waste in accordance with its role.

5) So there are some aspects of the arrangements in this regulation includes regulation of: (1) the policy and waste management strategies, (2) implementation of waste management, (3) compensation, (4) the development and application of technology, (5) information systems, (6) the role of society, and (7) coaching.

This Government Regulation requires the District/City Government to have policies and strategies on waste management. In addition, the Regency/City Government is required to have master plan documents and feasibility studies of household waste management and similar household garbage. It also places significant emphasis on the business world to participate in the waste management process. The business world is not simply recommended but it is required to reduce waste generation and use packaging that is easily broken down by natural processes. Manufacturers are required to participate in the process of recycling waste and reuse waste products.

Specifically to the District/City Government, there is an obligation to provide waste separation facilities consisting of decomposable waste, recyclable waste, and other waste within a maximum of 3 (three) years since this Government Regulation takes effect. As for the provision of waste segregation facilities consisting of garbage containing hazardous and toxic materials and hazardous and toxic waste, decomposable waste, reusable waste, recyclable waste, and other waste, the District Government is given time Maximum
5 (five) years. Through the Local Regulation (Perda) of Denpasar No. 3 year 2015 [4] and the Regulation of the Mayor (Perwali) Denpasar Number 11 year 2016 has been regulated about waste management with the approach of the environment that is in effect effectively on July 1, 2016 [5]. The environment in question is the smallest community unity called banjar, dusun, neighborhoods that exist in each desa adat and official village (administrative).

Minister of State for Environment, Balthasar Kambuaya stated that Government Regulation No. 81 year 2012 will realize environmentally friendly waste management based on 3R implementation in the framework of saving natural resources, energy saving, development of alternative energy from waste processing, environmental protection, and pollution control 3]. Thus the legal issue to be discussed as a problem is: How is the model of coexistence between state law and customary law in waste management in Denpasar City which is known as one of the world tourism distination?

\section{Method of Research}

The kind of research used is in the form of normative legal research equipped with empirical legal research or sociology research $[6]^{2}$ with the reasons that is still found the existence of behavioral deviation in disposing of waste that is not based on banjar / environment. This research uses several approaches, such as: statute approach, analytical approach, case approach, law anthropology approach, custom law approach $[7]^{3}$, and cultural approach $[8]^{4}$. Legal anthropology pays attention to the phenomenon of legal pluralism in society. It is relevant to what Roger Cotterrell states: We should think of law as a social phenomenon pluralistically, as regulation of many kinds existing in a variety of relationships, some of the quite tenuous, with the primary legal institutions of the centralized state. Legal anthropology has almost always worked with pluralist conseptions of law [9]. ${ }^{5}$

The choice of this legal anthropological approach, based on the fact that the people of Indonesia and the cultural complexity of each is plural. It is also heterogeneous (a variety) which indicates a quality of the state that holds inequality in its elements, meaning that each subgroup of society and its culture are completely different 10$]^{6}$. Van Vollenhoven in the twentieth century identified the existence of 19 customary law environments, which were later developed into 24 circles of customary law by Ter Haar. From this construction can be observed the existence of various customary law environments in

2 H. Zainuddin Ali. 2013. Metodologi Penelitian Hukum. Cetakan keempat. Remaja Rosdakarya. Jakarta. Pg. 12.

3Johnny Ibrahim. 2006. Teori \& Metodologi Penelitian Hukum Normatif. Edisi Revisi. Cetakan Kedua. Bayumedia Publishing, Malang Jawa Timur, pg. 98.

4 Mudji Sutrisno, SJ, 2013, Ranah-Ranah Kebudyaan, Cetakan ke 5, Kanisius, Jakarta, pg. 25.

5 Roger Cotterrell. 1995. Law's Community, Legal Theory in Sociological Perspektive. Oxford, USA. Clarenco Press. P. 306.

6Budiono Kusumohamidjojo. 2000. Kebhinekaan Masyarakat Indonesia, Suatu Problematik Filsafat Kebudayaan, PT. Grasindo. Jakarta. pg. 45. 
Indonesia [10]..$^{7}$

The above statement shows a tendency to be able to reward cultural variations in which there are laws (customs) of each indigenous and tribal peoples. Therefore the problem in the study will be relevant to be studied in relation to the concept of legal pluralism as expressed by Hooker that is related to the special situation when the state law "recognizes" some form of "customary law" which is then developed in the concept of "coexistence".

The combination of this approach is meant to know the "living law". It is also meant to be complementary, meaning that from legal anthropology, customary law can get input about the description of society structure and socio-cultural factors underlying the rule of adat law. So in the activities of legal anthropology can be combined knowledge of customary law that is dogmatic-normative with the reality [11]. ${ }^{8}$

The data in this research is obtained by observation technique which is completed with interview from informant or respondent. In addition, the data are also obtained from the second source that is primary legal materials, secondary materials collected by documentation techniques and recording with the model file [12] ${ }^{9}$. The data were then analyzed using hermeneutics analisys technique [7]. ${ }^{10}$

\section{Conceptual Base}

Garbage is the rest of the daily activities of human and / or natural processes in the form of solid, while household waste is garbage derived from daily activities in households that do not include stools and specific waste. Thus affirmed in Article 2 sub-article 6, 7 Local Regulation (Perda) Denpasar City No. 3 Year 2015 on Waste Management [4]. It is also known as organic waste and inorganic waste. Organic waste is waste consisting of biodegradable and naturally occurring materials. While inorganic waste is biodegradable biodegradable waste, such as plastics, bottles, cans.

Garbage can be disposed of to a temporary waste disposal site (TPSS) is a place where before garbage is transported to integrated recycling, processing and / or waste treatment plant (TPST), the place where collection, sorting, reuse, recycling, processing and final waste processing. As a final disposal, final disposal site (TPA) is a place to process and return waste to environmental media safely for humans and the environment.

Conceptually through regulation made by District Government, waste management is oriented to reduce waste generation through $3 \mathrm{R}$ principles (reduce, reuse, recycle)

\section{Ibid.pg. 47.}

8Valerine Jaqueline Leonore Kriekhoff. 1991. "Kedudukan Tanah Dati sebagai tanah adat di Maluku Tengah, suatu kajian dengan memanfaatkan pendekatan antropologi hukum". Disertasi. Program Doktor Ilmu Hukum Fakultas Pasca Sarjana Universitas Indonesia. Page. 57.

9I Made Suwitra, 2009, "Eksistensi Hak Penguasaan dan Pemilikan Atas Tanah Adat di Bali dalam Perspektif Hukum Agraria Nasional", Program Doktor Ilmu Hukum Fakultas Hukum Brawijaya, Malang, page. 51.

10Johnny Ibrahim. 2006. Op. cit. page 102. starting from sources such as Household and other producers, ie managers of residential area, commercial area, industrial area, Special areas, general facilities, social facilities, and other facilities (Article 3 Regent Regulation of Klungkung Regency No. 26 of 2016) [13]. It is also accompanied the establishment of Garbage Bank in several villages as a pilot project by involving the participation of Non-Governmental Organizations in the field of environment and the integration of the use of simple technology with the aim of reducing waste disposed to TPA (Denpasar Mayor Decree No. 188.45 / 195 / HK / 2015 about Stipulation of Garbage Bank), so that there are 28 Garbage Banks funded from APBD (Budget and regional Income) of Denpasar City The obligation of garbage bank is:

a) Carrying out waste management and hygiene handling efforts in their respective areas;

b) Sorting and processing organic and non organic waste into goods that have economical and efficient value in efforts to reduce the burden of waste in landfill (TPA);

c) Serving, preparing and collecting public waste in its area for recycling;

d) Receiving public waste that can be converted in the form of money that can be saved and booked on a passbook;

e) Implementing the learning activities to the public of environmental hygiene; and

f) Preparing the personnel, facilities and infrastructure needed for the implementation of sanitary self-cleaning activities [14].

Based on banjar and desa adat 'customary village' means that waste management is oriented to be managed by the smallest community of indigenous communities in Bali called banjar. While administratively (service) is called hamlet / neighborhoods. While customary village is a community of customary law community that is larger, because in customary village usually consists of more than 1 (one) banjar. Customary village with its banjar is the spearhead of the implementation of the development process in Bali. The successful implementation of all government programs due to the active participation of indigenous villages with banjar, such as family planning, Pos Yandu (babies service), AMD, Month of Service LKMD (Village empowerment). In Bali to date other than known there are customary village, there is also an official village or administrative village that is directly in that sub-district and regulated in state law such as Law No. 6 Year 2014 on the village [15].

The customary village with its own autonomy has been able to regulate itself in accordance with its customary law known as Awig-Awig both inside and outside by following the laws of the country and living side by side with the administrative / administrative village in the context of duality. Recognizing the strategic role of indigenous villages in the development process, the more complex management of waste problems will be examined from the concept of "coexistence" between indigenous villages with administrative and Cityities as well as coexistence between 
customary / Awig-Awig as folks law and state law.

\section{Theory Base}

The theory used in the form of the theory of law as a social engineering function as disclosed Roescoe Pound, namely: Set sup social engineering as the crucial task of all thought about law. Toward that task, he formulates and classifies social interests. Legal progres is acheived by balancing these interest [17]. ${ }^{11}$ Law as a means "social engineering", it is intended that the law serves to bring about changes in society. Under these conditions law is used to generate a real social change [18]..$^{12}$ The function of law as a tool of social engineering (law as a tool of social engineering) is one of proponents of Sociological Jurisprudence [19]. ${ }^{13}$

He classifies legally protected interests in three major categories: (a) public interests; (b) individual interests; and (c) social interests. (a) Public interests include the interests of the sate (i) in subsisting as a sate and (ii) in acting as a guardian of social interests. (b) Individual interests consist of (i) interests of personality, such as protection of physical integrity, freedom of wol, reputation, privacy, and freedom of belief and opinion; (ii) interests of domistic relations, suci as protection of marriage, maintenance claims, and legal relations between parents and children; and (iii) interests of substance, suci as protection of property, freedom of testation, freedom of industry, and contract.(c) Social interests are composed of interests in (i) general security, (ii) security of social institutions, (iii) general morals, (iv) pretection of social resources from waste, (v) general progres, and (vi) individual human life. He classifies legally protected interests in three major categories, namely: (a) the public interest, (b) the interests of the individual, and (c) the public interest.

Pospisil asserts that law is studied as an integral part of culture as a whole, not as an autonomous institution separate from other cultural aspects. So to understand the place of law in the structure of society, it must be understood in advance the social life and culture of society as a whole [20]. This statement is relevant to what Hoebel discloses: We must have a look at society and culture at large in order to find the palace of law within the total structure. We must have same idea of how society works before we can have a full conception af what law is and how it works $\left[21 .^{14}\right.$ Therefore it will be very relevant also with the theory of legal theory as a system (the legal system) [22 $]^{15}$ as Friedman disclosed,

11 Surya Prakash Sinha. 1993. Jurisprudence Legal Philosophy in A Nutshell, ST. Paul, Minn, West Publising CO. Page 233.

12Satjipto Rahardjo. 1986. Hukum dan Masyarakat. Angkasa. Bandung. page. 117.

13Darji Darmodiharjo dan Shidarta. 1996. Pokok-Pokok Filsafat Hukum, Apa dan Bagaimana Filsafat Hukum Indonesia. Edisi Revisi. Cetakan Kedua. PT. Gramedia Pustaka Utama. Jakarta. page. 129

14 E. Adamson Hoebel. 1954. The Law of Premitive Man, A Study in Comparartive Legal Dynamics. Cambridge, Massachusetts. Harvard University Press. P. 5.

15Lawrence M Friedman. 1975. The Legal System: A Social Science Perspective, Rusell Sage Foundation. New York. P. 14-15. It can be also seen in I Nyoman which is as follows:

1. The law as a system essentially has three elements, namely: (a) the structure of the legal system consisting of the legislative body, the institution of the court with its structure, the prosecutor's institution with its structure, the state police agency functioning as law enforcement officers; (b) the substance of the legal system in the form of legal norms, legal regulations, including patterns of public behavior that lie behind the legal system; And (c) the legal culture of society such as values, ideas, expectations and beliefs embodied in the behavior of society in perceiving the law.

2. Every society has its own legal structure and substance. Which determines whether the substance and structure of the law is obeyed or not the attitudes and behavior of civil society and therefore to understand whether the law is being effective or not depends on the habits (customs), culture, traditions, And informal norms that are created and operationalized in the society concerned.

\section{Waste Management on Lingkungan/Dusun/Banjar}

Denpasar City Government has prepared changes to Lingkungan/Dusun/Banjar-based waste management regulation through Mayor Regulation No. 11 of 2016 and came into effect July 1, 2016. After July 1, garbage disposal primarily from households are required to have been separated (organic and inorganic) directly taken to TPSS either individually or through a carrier managed servicesbased on Lingkungan/Dusun/Banjar (self-management) and no longer put the garbage in front of the house / alley. Previously, the garbage disposal from the community was arranged in such a way that the citizens were obliged to issue the garbage at 17.00 Wita - 19.00 Wita which will be transported by DKP [23]. With various evaluations this transport model caused traffic jams, especially when garbage trucks raise garbage from households who have put their garbage in front of houses, alleys, sidewalks. Therefore, the regulation changes to its Lingkungan/Dusun/Banjar-oriented management model.

Banjar/Dusun/Lingkungan based waste management means the management of waste through the reduce, reuse and recycle (3 R) approach in each Banjar/Dusun/Lingkung in the Village / Customary Village. Furthermore, the rest of the waste is taken to TPSS through the Banjar / Dusun / Lingkngan-based Village self-management. Every village is expected to have a Waste Bank. So that only the residue is discharged to the landfill.

Mayor Regulation No. 11 of 2016 has been socialized by the Team to all Sub-district Head, Village Head, Perbekel / head of village, Bendesa Adat and all Head of Banjar and Head of Dusun in Denpasar. All agreed to note that TPSS

Nurjaya. 2006. Page. 34. 
should be provided in each Banjar / Dusun or village / customary village can be facilitated to use TPSS in other Banjar / Dusun or village / customary village when Banjar / Dusun and village / customary village concerned does not have land to TPSS [23].

This Mayor Regulation provides an additional task to the Head of Dusun and Kepala Desa / Perbekel to form a selfmanaged group that will transport the waste to TPSS. While the garbage collected in TPSS will be transported to TPA by the Department of Hygiene and Gardening (DKP). To smooth the task at the village level in support of Mayor Regulation No. 11, the City Government (City Government) has provided 40 Motor Cikar (Moci) to the head of village
Head / Perbekel. While the number of Dusun/Lingungan/ hamlets / Banjars is 406/360. So there is a gap between the amount of Moci assistance and the number of Banjar/Dusun/Lingkungan available, because the waste management is designed based on Banjar/Dusun/Lingkungan.

For more details can be considered the amount of Dusun/Lingkungan and Banjar in each village / customary village of each District in Denpasar City, as in the table as follows:

Data of Dusun/Lingkungan / Banjar and village / customary village in Denpasar.

Table 1. Data of Dusun /Lingkungan / Banjar and village / customary village in Denpasar.

\begin{tabular}{lllllll}
\hline \multirow{2}{*}{ No } & \multirow{2}{*}{ District } & Village & & \multicolumn{2}{c}{ Dusun/Lingkungan/ Banjar } \\
\cline { 2 - 6 } & & Keperbekelan & Kelurahan & Customary village & Official & Custom \\
\hline 1 & Denpasar Selatan & 4 & 6 & 11 & 105 & 92 \\
2 & Denpasar Timur & 7 & 4 & 12 & 87 & 91 \\
3 & Denpasar Barat & 8 & 3 & 2 & 112 & 118 \\
4 & Denpasar Utara & 8 & 3 & 10 & 102 & 59 \\
Total & & 27 & 16 & 35 & 406 & 360 \\
\hline
\end{tabular}

From this table looks Moci assistance is on villages / kelurahan. While waste management is expected to be based on Banjar / Dusun/Lingkungands, so there is still a gap between Moci assistance with the number of banjar / Dusun/Lingkungan.

Since 2015 the Denpasar City Government has facilitated the establishment of 28 Garbage Banks which are funded from APBD and by combining waste management based on Banjar/Dusun/Lingkungan, it is believed that waste disposed to TPA is only a residue that can not be utilized for compost and ore.

Denpasar City Government also has integrated technology in waste processing, one of them with garbage ATM machine that has been installed in Pasar Kreneng and Gunung Talang Road. In the future it has programmed to implement waste processing machine with DRS technology (dry, reduce, scubbing). With this technology waste is not processed into the waste disposal to the final disposal (TPA). Waste processing through DRS technology is very environmentally friendly because the result of organic fertilizer or plastic ore that can process waste of 2000 tons per month.

Paul Connet appreciated the commitment of Denpasar Mayor to overcome the garbage problem in Denpasar City, which was delivered during the exposure of waste incident with Zero Waste in front of Mayor, City Secretary, Head of village / Perbekel / Lurah, non-government organization environmental activist. Paul saw the Mayor of Denpasar has a high commitment in dealing with hygiene issues and is a leader who is concerned with the waste problem, because so far there is handling of waste well.

To realize Zero Waste is possible, because the government's commitment already exists, just to increase the participation of the community and all environmentalists. Denpasar is one of the tourist destinations. Future waste processing can be used as an environmental tourism object, surely this will open the job field and can realize Zero Waste.

Waste processing with Zero Waste has been implemented in several countries that have the same problems as in Denpasar, especially characteristic of garbage in Denpasar $50 \%$ in the form of organic garbage. At that time was introduced circular economic waste management system that is in accordance with the characteristics of garbage Denpasar which $50 \%$ wet.

There are nine steps in this concept: source sparation, door to door collection, cokposting, recycking, reuse and repair center, zero waste research, better industrial desaign, reducing throwaway product and packaging and residual separation facility. The emphasis of the concept offered is the handling of the source of waste production, which is the waste that is separated from the beginning with the responsibility of society, the government only handles the waste residue. This method is estimated to reduce $80 \%$ of waste to landfill.

The mayor stated that Paul offers sustainable waste that has been successful in some countries, such as the Philippines. The tough challenge ahead is to invite the entrepreneur to ridesaign the product so that it can be processed again. Therefore, the community is more empowered for the community to sort the waste from the source (household). In the future, the garbage problem can be solved at the Dusun/Lingkungan / banjar level.

The waste management of Banjar / Dusun/Lingkungan based and custom / rural villages is done by exposing the legal aspects / rules (legal substance) between the state law (Local and Mayor Regulation / Regents Regulation) with customary law as the law of the people (Awig-Awig), exposing legal structure, namely the supervision and law enforcement of each violation, that is the existence of joint work between state / regional government apparatus (Satuan Polisi Pamong Praja) with the customary village government 
apparatus (Banjar / customary village officers) and administrative village administration (Hansip and Pecalang) and the support of city residents consisting of krama banjar / customary village and other residents of Denpasar that exist in each region of traditional village to jointly create social order as a reflection of clean and orderly living law culture.

The coexistence between state law and customary law can give more strength, especially in the supervision and enforcement of the law, as well as strengthening the commitment of society as citizens, because waste management will succeed if supported by the participation of the community as a whole. Community participation in Bali can be maximized if based on Banjar/Dusun/Lingkungan in village/customary village, since the community as a whole garbage producer is part of Banjar/Dusun/Lingkungan in village/customary village as the community of the lowest law community in totality.

The waste management that is based on Banjar/Dusun/Lingkungan in village/customary village will be effective in solving the complexity of waste problem in Denpasar, such as Sanur Village with its Garbage Bank. However, it can not be implemented in other banjar / neighborhoods and village / customary village as a whole. Therefore it is issued Mayor Regulation No. 11 of 2016 which requires all Banjar/Dusun/Lingkungan and village / customary village to manage waste, so that the garbage has been sorted from the source to be disposed to TPSS or managed by $3 \mathrm{R}$ system through TPST or Bank Trash, so that is dumped into TPA is only waste that can not be utilized. With the support of technology in the processing of garbage and combined with self-reliant community based on Banjar / Dusun/Lingkungan and village / customary village through the separation of garbage from the household of course the problem of waste will be overcome.

Supervision and law enforcement against violations of regional regulations on waste management can be done by exploiting the tasks of the civil service police unit as regulated in the regional regulations with pecalang, as regulated in Awig-Awig of desa adat 'customary village'. So supervision and law enforcement are a very important part of the legal system and will determine the effectiveness of the rule of law. It is relevant to be made by Jagakota Team (Public Alert Network Community of Denpasar) by civil service police unit of Denpasar Government with the aim to keep order and peace of society and suppress violation of local regulation, because maintaining order and security of town not only become responsibility of civil service police unit but all components of society. In addition, the reason, because the personnel and funds are so limited that it can not conduct supervision and enforcement of all violations that occurred. It may be clichéed, but it will still be the most powerful justification.

Jagakota (keep the city) team will be expected to solve the increasingly complex city problems. Team Jagakota involves components of police, military, Pecalang, CBOs, Kerta Sabha Upadesa, Bendega forum, forum pekaseh, Hansip, Youth, STT, NGOs are concerned about the environment and garbage. All have their respective roles to keep the city safe. Through the innovative program, try to find solutions to solve the problems of Denpasar City. Observing the purpose of establishing the Jagakota team, the development of the concept of coexistence of the existing legal structure would be relevant for generating the effective implementation of Mayor Regulation No. 11 year 2016 of waste management based on Village who is impelemented by Banjar/Dusun/Lingkungan. So the city of Denpasar as a tourist destination can maintain aspects of security, comfort for both citizens and for tourists.

The effectiveness of the law or the work of the law as a system is also determined by the support of the legal culture of the society supporting the law itself. The support of legal culture is reflected in the commitment and behavior of the community in the ability of waste management based on Banjar/Dusun/Lingkungan in customary village / village. This means that the garbage of the existing community in each Banjar/Dusun in the customary village / village container is managed in each Dusun/Lingkungan through the garbage bank and then taken to TPSS as the remaining management with $3 \mathrm{R}$ systems.

Various efforts in handling waste with the management model has been done by the Government of Denpasar City including various innovations. However, these efforts will have no meaning if there is no supervision and law enforcement against the violators. Therefore, the Village based waste management model that involves the legal structure up to the lower level, ie banjar / neighborhoods / hamlet and at the same time customary village / village will be able to run well or effectively through applying coexistence concept in field of supervision and law enforcement by legal structure, that is the City government carried by the civil service police unit, along with the village government and customary village apparatus represented by pecalang in the enforcement of the regional regulation. While the monitoring and complaint is done by the community as a whole both as citizens in administrative village government as well as indigenous people in custom village government so that its supervision is inherent and give responsibility to the society.

The development of coexistence concept also applies to legal substance in Banjar/ Dusun/Lingkungan in customary village /administrative village waste management, meaning that waste management arrangement is done by expanding the local regulation with the customary village Awig-Awig. So the garbage disposal to TPSS is done directly by the producers after being sorted out or through the management services in each Banjar/Dusun/Lingkungan and customary village / village, so there is no more waste disposal schedule, because DKP only transports from TPSS to TPA to prevent piles of garbage at each end of the alley, roadside or in front of residents' houses.

In some Banjar/Dusun/Lingkungan in the villages / customary villages that have not used this model, the garbage heap waiting for transportation can always be found at each end of the alley or in front of the house / shop. Also the 
garbage can be found on the vacant land, as well as in the

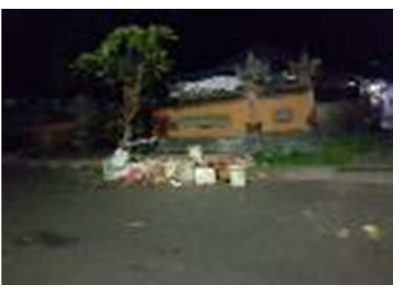

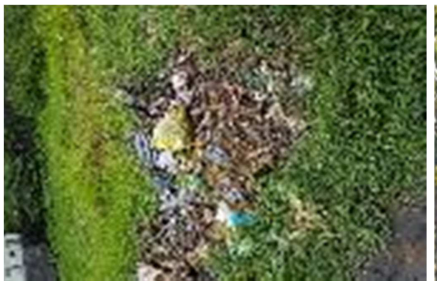

pots as shown in the picture below.

Figure 1. Problem of Waste.

The waste management based on Banjar / Dusun/Lingkungan and customary village / village can run effectively based on the development of coexistence between legal substance, legal structure and legal culture and by exposing state law and customary law.

\section{Conclusion and Recommendation}

Until now, rubbish in Denpasar City is still a problem because not all villages manage waste independently through the Trash Bang, but most of them still carry out the transportation and transportation of conventional rubbish, namely transport and dispose. Likewise, market waste and garbage after traditional ceremonies are still managed conventionally. This rubbish problem becomes more complicated than the private sector (PT. NOI), which was initially approved to manage the trash in the landfill, not a place capable of continuing its funds because in the electricity company the Suwung landfill.

TPA Suwung overloaded and caused smoke and odor pollution. As a result, the Banjar Pesanggaran community in the TPA environment held a demonstration to block the garbage trucks from dumping garbage into the TPA. As a result, districts in the SARBAGITA area (Denpasar, Badung, Gianyar, and Tabanan) are in chaos, because they do not yet have a permanent landfill. While rubbish in the city of Denpasar until now has not been completed, plus there are still people throwing trash randomly.

The Banjar/Dusun/Lingkungan-based waste management pattern in the Customary Village / Administrative Village is intended to answer the problem of the complexity of waste management that is never finished. By developing the concept of coexistence between state law with customary law and between official government with customary government in legal system theory, the problem of waste can be managed independently by the smallest community known as the Banjar/Dusun/Lingkunga in the Customary Village/Administrative Village through the Garbage Bank. So the waste can be managed effectively in the Customary Village is colled Desa Adat who coexistence with Administrative Village through the Garbage Bank using the Banjar/Dusun/Lingkungan approach, such as the Sanur Village so that the garbage dumped into the landfill is only residual waste from the management of the Garbage Bank.

Considering this condition, it is better for waste management to be carried out through the Village-based Garbage Bank that is carried out by the
Banjar/Dusun/Lingkungan as the lowest community of the government. Supervision and law enforcement must be carried out on the basis of Customary Villages/Administrative Village through Banjar/Dusun/Lingkungan as a source of waste production as well as a source of violations and a source of success of the City/ Regency Government. Therefore, the City Government must continue to encourage the establishment of Garbage Banks in each Village and monitor their effectiveness including the budget which supports village funds. So the concept of coexistence both in the field of law (state law and folk law) and in the field of government (official and customary) becomes important especially for Bali which still knows duality in the village government, namely Desa Dinas (Keperbekelan) and Desa Adat (Kebendesaan.

\section{References}

[1] Adamson Hoebel. E. 1954. The Law of Premitive Man, A Study in Comparartive Legal Dynamics. Cambridge, Massachusetts. Harvard University Press.

[2] Budiono Kusumohamidjojo. 2000. The Diversity of Indonesian Society, A Cultural Philosophy Problems, PT. Grasindo. Jakarta.

[3] Darji Darmodiharjo dan Shidarta. 1996. The Principal of Law philosophy, What and how The Law Philosophy of Indonesia. Revised Edition. Second Printing. PT. Gramedia Pustaka Utama. Jakarta.

[4] Johnny Ibrahim. 2006. Teori \& Metodologi Penelitian Hukum Normatif. Revised Edition. Second Printing. Bayumedia Publishing, Malang Jawa Timur.

[5] Koentjaraningrat. 1976. Human and Culture in Indonesia. Jambatan. Jakarta.

[6] Leopold Pospisil. 1971. Anthropology of Law a Comparative Theory. Harper \& Raw Publishers. New York, Evanston, San Francisco, London.

[7] Lawrence M Friedman. 1975. The Legal System: A Social Science Perspective, Rusell Sage Foundation. New York. P. 14-15. Can also be seen in I Nyoman Nurjaya. 2006.

[8] Mudji Sutrisno, SJ, 2013, Cuklture Domains, Fifth Printed, Kanisius, Jakarta.

[9] Ronny Hanitijo Soemitro. 1983. Law Research. First Printing. Ghalia Indonesia. Jakarta. Page 9 mentioned the term of doctrinal Law Research. 
[10] Roger Cotterrell. 1995. Law's Community, Legal Theory in Sociological Perspektive. Oxford, USA. Clarenco Press.

[11] Satjipto Rahardjo. 1986. Law and Society. Angkasa. Bandung.

[12] Suwitra, I Made. 2009, "The Existence Ruler and Ownership on Customary Land in Bali in National Agrarian Law Perspective", Doctoral Program of Law. Faculty of Law Brawijaya University Malang.

[13] Surya Prakash Sinha. 1993. Jurisprudence Legal Philosophy in A Nutshell, ST. Paul, Minn, West Publising CO. Page 233.

[14] Valerine Jaqueline Leonore Kriekhoff. 1991. "The Position of Dati Land as customary land in Central Maluku, a study by law anthropological approach". Dissertation Doctoral Program of Law Faculty of Postgradutae Indonesia University.

[15] The Act of Republic of Indonesia No 18 of 2008 on Waste Management. Gazetted of Republic of Indonesia 2008 No 69. Additional Gazetted of Republic of Indonesia No 69.

[16] Government Regulation of Republic of Indonesia No 81 on Domestic Wast Management and Similar Domestic Waste.
[17] The Regulation of Bali Province No 5 of 2011 on Waste Management. Local Gazetted of Bali Province of 2011 No 5. Additional Local Gazetted of Bali Province No 5.

[18] The regulation of Denpasar City No3 of 2015 on Waste Management. Local Gazetted Denpasar City of 2015 No 15, Additional Local Gazetted of Denpasar City No 3.

[19] The Regulation of Klungkung Regency No 7 of 2014 on Waste Management. Local Gazetted of Klungkung Regency of 2014 No 7 Additional Local Gazetted of Klungkung Regency of No 4.

[20] The Regulation of Denpasar Mayor No 11 of 2016 on the Management Procedure and Waste Disposal in Denpasar City.

[21] The Regulation of Klungkung Regent No 26 of 2016 on Regulation application Local Regulation Peraturan of Klungkung Regency No 7 of 2014 on Waste Management.

[22] The Decree of Mayor of Denpasar No 188.45/195/HK/2015 on Garbage Bank Settlement in Denpasar City.

[23] The Exclamation of the Government of Denpasar City No $658.5 / 2114 / \mathrm{DKP}$ on The Management of Waste Disposal Time. 